\title{
IAMJ
}

INTERNATIONAL

AYURVEDIC

MEDICAL JOURNAL

Impact Factor: 6.719

\section{AYURVEDIC MANAGEMENT OF GRAHANI ROGA- CASE REPORT}

\author{
Aparna. T. P' ${ }^{1}$ Archana. S. Dachewar ${ }^{2}$ \\ ${ }^{1}$ MD Scholar, Department of Kayachikitsa, Shri Ayurved Mahavidyalaya, Nagpur, Maharashtra, India \\ ${ }^{2}$ Guide, Professor and HOD, Department of Kayachikitsa, Shri Ayurved Mahavidyalaya, Nagpur, Maharashtra, \\ India
}

Corresponding Author: 4aparnatp@gmail.com

\section{https://doi.org/10.46607/iamj4109112021}

(Published Online: November 2021)

Open Access

(C) International Ayurvedic Medical Journal, India

Article Received: 31/10//2021 - Peer Reviewed: 07/11/2021 - Accepted for Publication: 08/11/2021

\section{Check for updates}

\section{ABSTRACT}

Grahani Roga is a disease of Annavaha Srotas caused due to the formation of Ama due to Mandagni. Elimination of Vidagadha or Apakva anna through the Guda is known as Grahani Roga. Acharya Charaka has mentioned that the improperly digested food due to Mandagni when moved either in Urdhwa or Adho-Marga leads to Grahani Roga. Acharya Sushruta and Madhavakara have mentioned that patients of Atisara, during the stage of Agnimandya, if taken virudhha ahara, may lead to Grahani Roga. Muhur Baddha Muhur drava mala pravritti (altered bowel habit), Shleshma mala pravritti (mucous in stool) are the main symptoms of this disease. The symptoms of Grahani resemble most irritable bowel syndrome (IBS) symptoms. So, we can correlate the Grahani roga with IBS. A diagnosed case of Grahani (IBS) is discussed here who was treated with Bilwavaleha, Sanjeevani Churna, Arogyavardhini vati, Brahmi vati, Manasamitravatakam and Hingwashtak churna.

Keywords: Grahani roga, IBS, Agnimandya, Case report

\section{INTRODUCTION}

Globalization, fast modern life, and the growing trend of nuclear families have brought huge amounts of changes in our lifestyle and the quality of our living.
The trend of junk food, instant fast food and adulteration of food items has suppressed the concept of complete and balanced nutrition and also has 
degraded the quality of food these days. Stress to survive in a very competitive world adds up to the problems. All these very badly affect the normal physiology of our body. This points out the clinical relevance of understanding and treating the disease Grahani as it is directly related to the improper lifestyle and food habits of people. The seat of Agni which retains the food until it is fully digested is called Grahani. After digestion, it passes into Pakwashaya. As per Acharya Sushruta Grahani is the $6^{\text {th }}$ Pittadhara Kala situated between Amashaya (Stomach) and Pakwashaya ${ }^{l}$. Acharya Charaka has mentioned it is the part that is situated above Nabhi (Umbilicus) and is supported and nourished by the strength of Agni. Grahani (organ) digests the food and releases it into the next Ashayas i.e., Pakwashaya ${ }^{2}$. The disease where there is impairment of Agni and Grahani gets vitiated is called Grahani Roga. Disturbed digestion is the main pathology seen in Grahani. It produces symptoms like Atisrushta Atibadha Mala (loose/constipated), Trushna (Thirst), Arochaka (tastelessness), Aasyavairasya (Altered taste), Praseka (excessive salivation), Shoona Pada Kara (oedema over hands and feet), Asthisara Ruk (pain in phalangeal joint and bone), Chhardi (vomiting), Jwara (fever), and Louhagandhi Amlodgara (iron pungent odour burps) ${ }^{3}$.

Irritable bowel syndrome (IBS) is a vague term for a variety of diseases causing discomfort in the GI tract which causes great morbidity in the population. It is a functional bowel disorder characterized by chronic abdominal pain, discomfort, bloating and alteration of bowel habits in the absence of any organic cause. Psychological factors like stress, anxiety etc., play an important role in the manifestation of IBS. It is characterized by recurrent abdominal pain and abnormal defecation in the absence of a structural abnormality of the gut ${ }^{4}$.

\section{MATERIAL AND METHODS}

\section{Case Report}

A 37-year-old housewife, who was a clinically diagnosed case of IBS, came to the Kayachikitsa OPD (Regn. No: OPD20-32030) of Pakwasa Samanway Rugnalaya, Nagpur on $27^{\text {th }}$ October 2020, having chief complaints as Dravamala pravritti (Frequent loose motions) after having food, sometimes Malabadhata (Constipation), Apakwa malapravritti (Mucous stools), Adhmana (Bloating), Daurbalya (Weakness) Kshudhamandya (Loss of Appetite), and Alasya (Fatigue) since one and a half years. She also has abdominal pain for six months which gets relieved after passing stool.

\section{History of Present illness}

The non-hypertensive, non-diabetic patient was asymptomatic before one and a half years. She has taken treatment from various hospitals and did not get any complete relief. A colonoscopy procedure was done before 6 months which did not reveal any underlying pathology. Following that she has taken antacids and antispasmodic drugs unevenly.

\section{General Examination}

Vitals General condition of the patient was fair

Pulse: 70/min; Temp.: Afebrile

BP: $120 / 70 \mathrm{~mm}$ of $\mathrm{Hg}$; RR: 18/min

Weight: $42 \mathrm{~kg}$, lean built

\section{Systemic examination:}

CVS: $\mathrm{S}_{1} \mathrm{~S}_{2}$ Normal, no abnormal sound was heard

CNS: Conscious and oriented

RS: Chest clear, $\mathrm{AE}=\mathrm{B} / \mathrm{L}$

P/A: Soft with mild tenderness in right lumbar and umbilical region

Mild pallor was observed

\section{Ashtavidha Pareeksha}

Nadi: Pitta pradhana vata: Mutra: Samyak, 56times/day

Mala: Muhurbadha muhursrishta (5-6 times/day): Jihwa: Alpasama

Shabda: Spashta, Sparsha: Samasheetoshna

Drik: Spashta, Alpa panduta, Akriti: Krisha

Blood Investigations

$\mathrm{Hb} \%$ : $10.5 \mathrm{~g} / \mathrm{dl}$; other complete blood count values were within normal limits.

ESR: $35 \mathrm{~mm} / 1^{\text {st }} 1$ hour

FBS: $90 \mathrm{mg} / \mathrm{dl}$

\section{TREATMENT}

1. Bilwavaleha $10 \mathrm{gm} \mathrm{BD}$

2. Sanjivani Churna $1 \mathrm{gm} \mathrm{BD}$

3. Arogyavardhini vati $500 \mathrm{mg} \mathrm{BD}$ 


\section{Brahmi vati $500 \mathrm{mg} \mathrm{HS}$}

5. Manasamitra vatakam 1 tab HS

6. Hingwashtak churna 3gm BD

The medicines Bilwavaleha, Sanjivani Churna, Arogyavardhini vati and Brahmi vati were given after food with koshna jala as anupana for 1month and Manasamitra vatakam was given for 10 days as HS with milk as anupana as the patient expressed mild anxiety. Hingwashtak churna was given with the first bolus of food with ghee twice a day. Along with the medicine, the patient was advised to follow the Pathyapathya of Grahaniroga. She was told to consume, laghu ahara, takrahara etc. and to avoid oily, spicy, heavy, and hard to digest food. Divaswapna, ativyayama, atichankramana etc were also advised to avoid. Follow up was taken every 7 days for 1 month.

\section{OBSERVATION}

During the first follow up the frequency of passing stools were reduced to $4-5$ times/day. During the $2^{\text {nd }}$ and $3^{\text {rd }}$ follow up there were marked relief in all of her symptoms but Adhmana was persisting. So, during the 3rd follow up Hingwashtak churna was given $3 \mathrm{gm}$ for seven days and was told to do moderate walking and other exercises. On the $4^{\text {th }}$ follow up day motion was normal in consistency with 1-2 times a day, she had an adequate appetite and no fatigue or weakness as her food intake and digestion was normal. Adhmana was also reduced markedly.

\section{DISCUSSION}

Grahani is the disease of Agnivikriti. The formation of Aamdosha at different levels is the main samprapti responsible for the disease. Bilva, due to its Kashaya, Tikta Rasa, Katu Vipaka and Laghu Guna acts as Agni Dipana and also Amapachaka. Kashaya Rasa and Ushna Virya help in reducing colonic motility. Sangrahi property of Bilva is very useful to treat the increased frequency of defecation and the consistency of stool. In Bilvadileha in addition to Bilva, Prakshepa Dravyas like Dhanyak, Jirak, Ela, Twak, Trikatu, Musta, have properties like Dipana, Pachana, Kaphahara, Vedanasthapak, Rasayana. Sanjivani churna is good for relieving
Amdosha and is antimicrobial. Arogyavardhini vati as the name implies with its wide variety of actions improves health and is a potent digestive stimulant. Here improper digestion itself was the main problem. Manasamitravatam and Brahmi vati are ant-stress, anti-anxiety, and anti-depression properties. Hingwashtak churna is Agnivardhaka and Vatanulomana.

\section{CONCLUSION}

In the present study administration of Bilwavaleha, Sanjivani churna, Arogyavardhini vati, Brahmi vati, Manasamitra vatakam, and Hingwashtak churna are found to be very effective in curing the symptoms of Grahani. There was no adverse drug reaction seen during the time of treatment. So, from this case study, it can be concluded that Ayurvedic treatment is very effective in Grahani Roga.

\section{REFERENCES}

1. Ambikadatta Shastri, Hindi commentary, Sushruta Samhita (Uttar Tantra), Atisar Pratised Adhyay, Chaukhamba Sanskrit Sansthan Varanasi; 2012 p.306.

2. Astanga Hridayam of Shrimad Vagbhata Ed.by Brahmanand Tripathi Reprint Ed. Chaukhambha Sanskrit Pratishthan, Delhi 2017 P.762.

3. Vidyadhara Shukla, Ravi Datta Tripathi, Charak Samhita Vol.I (Chikitsasthana), Grahani chikitsa Adhyay, Chaukhamba Sanskrit Pratishthan, Delhi; 2012 p.369.

4. Harrison's Principles of Internal Medicine Ed.by Kasper, Braunwald, Fauci, Hauser, Longo, Jameson Reprinted. McGraw Hill 2005:1789.

\section{Source of Support: Nil Conflict of Interest: None Declared}

How to cite this URL: Aparna. T. P \& Archana. S. Dachewar: Ayurvedic Management Of Grahani Roga- Case Report. International Ayurvedic Medical Journal \{online\} 2021 \{cited November 2021\} Available from: HYPERLINK http://www.iamj.in/posts/images/upload/2890_2892.pdf 